\title{
The Role of the Project "Our Children: Windows of Opportunities" in Early Childhood Health Promotion
}

\author{
Danielle Freitas Alvim de Castro', Anna Maria Chiesa², Lislaine Aparecida Fracolli², \\ Lívia Keismanas Ávila ${ }^{1}$ \\ ${ }^{1}$ Nursing Department, School of Medical Sciences, Holy House of São Paulo, São Paulo, Brazil \\ ${ }^{2}$ Public Health Department, School of Nursing, University of São Paulo, São Paulo, Brazil \\ Email: dani facastro@hotmail.com, amchiesa@usp.br, lislaine@usp.br, liviakeis@yahoo.com.br
}

Received 5 April 2015; accepted 9 June 2015; published 12 June 2015

Copyright (C) 2015 by authors and Scientific Research Publishing Inc.

This work is licensed under the Creative Commons Attribution International License (CC BY).

http://creativecommons.org/licenses/by/4.0/

c) (i) Open Access

\section{Abstract}

This article intends to show that programs that intervene in early childhood promoting health and the development of the children improve many aspects of life, such as health, social, psychological, emotional, intelectual and cognition aspects. The project-Our Children: Windows of Opportunities - is an example of a program in Brazil that has the potential to intervene in families from the pregnancy and during the early childhood, strengthening the family potentials and assets so that the families can overcome their needs.

\section{Keywords}

Health Promotion, Early Childhood, Child Development

\section{Introduction}

In early childhood, the standards of behavior, learning and skills are set. The genetic heritage, which can be good or bad, is modified by social and environmental factors; the cells of the nervous system grow abundantly and neuronal circuits are established (Young, 2010).

At birth, the baby has more neurons than an adult needs. Their nervous system is not yet fully developed. The cells already exist but are not networked. Synaptic connections are established mainly over the first 3 years of a child's life. These connections are formed as the child learns and experiences the world around and relates to their caregivers (Shore, 2000).

The synapses are established when they are used and reinforced in daily child care, and then they become part 
of a permanent circuit in the child's brain (Shore, 2000).

Health, learning and psychomotor, social, psychological, emotional and intellectual behavior throughout the life cycle are influenced by the brain development during early childhood (Mustard, 2010). For example, regulation of the releasing of hormones to the gland system hypothalamic-pituitary-adrenal is influenced by external and internal stimulation since uterine life and in infancy (Mustard, 2010). These stimuli modify the operation of this circuit over the life (Mustard, 2010). Such a circuit affects memory, behavior, cognition, metabolism, the immune system and the cardiovascular system (Mustard, 2010).

In early childhood, the brain synapses are affected by the quality of education and the stimulus received during this period (Mustard, 2010).

Longitudinal studies have shown that the social environment influences the development of brain circuits that contribute to the development of learning, behavior and physical health throughout life (Mustard, 2010)

In early childhood care, nutrition, attachment, affection, stimulation, touch, play time and the refuge are determinants of a good physical, mental and social development (Chiesa, Veríssimo, \& Fracolli, 2009).

The quality of care and social interaction of children in the first years of life are crucial to a good brain development. This care increases the skill of thinking, self-confidence, the ability to problem solving and cooperation with others. These skills improve the child's performance in school and in the life trajectory (Young, 2010).

The literature shows that child development programs that work in a broader perspective in relation to nutrition, emotional and intellectual development and health stimulate the growth of healthy, capable and productive adults. Even those children who have been deprived of good opportunities for growth and development if they receive early intervention can change their life trajectories (Young, 2010).

Health Promotion and Child Development Programs can improve the trajectory of children in their life. Young (2010) stated that children who received early childhood interventions were likely to lower rates of truancy and better educational experiences.

The Perry Preschool Project, the North Carolina Abecedarian Project, the Infant Health and Development Program, Head Start and Early Head Start, the Integrated Child Development Service, the Proyecto de EducaciónInicial and Minding the Baby are examples of effective intervention programs in early childhood development (Young, 2010; Slade, Sadler, Dios-Kenn, Webb, Currier-Ezepchick, \& Mayes, 2005). As well as the Family Nurse Partnership has shown to be effective in reducing morbidity and maternal and child mortality, reduction of child abuse, child's emotional improvement and improvement in speech development of children when intervening in vulnerable families of adolescent mothers, following the children from pregnancy to 3 years of life (Olds, 2006).

The implementations of Health Promotion and Child Development Programs are needed in a reality such as Brazil, where there are still malnourished children without access to child care or an education with quality and often are deprived of a loving and affectionate family environment and good care.

Thus, thinking of the Health Promotion lines of action we need to think of healthy public policies in Brazil, such as the very National Health Promotion Policy (NHPP) and the National Policy for Primary Care (NPPC) that enable the implementation of intervention programs to promote child health and development, able to intervene (Brazil, 2006, 2010):

- In the environment favoritism;

- In participation in the community;

- The development of family skills; and

- In reorienting health services, to look the child care in a board perspective.

Health promotion contributes to the construction of actions that will respond to social needs in health. As a result, the NHPP proposes that health interventions extend beyond the walls of the units and the health system (Brazil, 2010). It is proposed to operate in the conditions of life and in favor of healthy choices. The object of health services becomes the problems and health needs, and their determinants and constraints (Brazil, 2010). Health professionals working in this perspective have the possibility to look at the child development in addition to their healthy growth and milestones of child development (sitting, standing, walking, talking, etc.).

In NPPC, the Primary Care looks at the subject in extended and comprehensive way, since it considers the subject in their socio-cultural integration in their uniqueness and complexity. In the Family Health Strategy, NPPC has its strategic priority for their organization, according to the precepts of the Unified Health System (UHS-Brazilians health system) (Brazil, 2006). The Family Health is a privileged space to act in an extended way and in the family locus, which allows the child development in a comprehensive and expanded way. 
“Our Children: Windows of Opportunities” is a Brazilian program that improves and promotes child health and development by strengthening families capacities for the daily care of the children such as play time, food time, hygiene time, sleep time and routine. This paper aims to present this program as a tool for family health teams to improve and promote health and child development.

\section{Health Promotion and Child Development-Our Children: Windows of Opportunities}

The Family Health Strategy (FHS), a Brazilian public health strategy, is a space that allows expanded actions beyond the biological and physiological care. It is a space where population health potential can be strengthened, as well as being a space of appropriate technologies development for a larger approach to care (Chiesa \& Batista, 2004).

In July 2001, to produce a technology with families in order to strengthen the dimensions of promotion of child health, the coordination of the Family Health Strategy of São Paulo’s Municipal Health Secretary signed an agreement with the United Nations Children's Fund (UNICEF) and the Blue Mountain Community Association (Chiesa, Veríssimo, \& Fracolli, 2009).

A technical group with representatives of institutions with experience in child development was formed to implement the proposal. On the technical group, there were representatives of the Recovery and Nutritional Education Center, Health of People with Disabilities, the Center for the Support of Culture and Extension activities of Public Health Nursing, School of Nursing of the University of São Paulo and the Child Pastoral (Chiesa, Veríssimo, \& Fracolli, 2009).

As the technical group product the Project Our Children: Windows of Opportunity was born (Chiesa, Veríssimo, \& Fracolli, 2009). The technologies of the Project have been constructed in accordance with the following assumptions (Chiesa, Veríssimo, \& Fracolli, 2009):

1) The importance of family involvement in child development;

2) The routine as child stimulation element within their different stages of development;

3) The experiences and opportunities offered by the family to facilitate the child's achievements;

4) The definition of steps and strategies to develop forms of care that need to be encouraged; and

5) The attitude of favoring a joint decision between health professionals and family about the need for specific assistance in overcoming difficult issues.

The project aims to promote child development, complementing the traditional approach focused on anthropometric assessment of the child and neurodevelopment milestones. The project's aim is to build integrated actions in several dimensions, such as affection, care, attachment and food, among others, that promote child development (Chiesa, Veríssimo, \& Fracolli, 2009).

Considering that the Family Health Strategy has a privilege space of care with families, the intention of the Project is to support family interventions, for daily care, such as feeding time, play time and the family relationship building actions that would promote child development in a positive way (Chiesa, Veríssimo, \& Fracolli, 2009).

For the construction of actions in daily care, the Project considered the opportunities for exercising the skills and the relationship of children to the development process (Chiesa, Veríssimo, \& Fracolli, 2009).

The project action content focused on the essential needs for child development, organized in the areas of (Chiesa, Veríssimo, \& Fracolli, 2009):

- Feeding;

- Hygiene;

- Accident Prevention;

- Love;

- Security;

- Play;

- Rights; and

- Participation.

The project act directly in the Family Health Teams to expand their vision about child development, in particular in relation to the child experiences in their family routine, and favoring links and proximity to all involved 
in the child care (Chiesa, Veríssimo, \& Fracolli, 2009).

The Family Health Teams should follow and record the development opportunities that families have offered to children from pregnancy to 3 years (Chiesa, Veríssimo, \& Fracolli, 2009).

The action content is assessed observing and talking with the families. For example, in relation to food, if the baby is still nursed were evaluated the quality of that breastfeeding, in addition to affection, attachment and touch. Another example would be in relation to the playtime, such as if the Family have a space to provide a time to play with the child. Who plays with the child? What kind of toys the family offers? Among other possibilities (Chiesa \& Veríssimo, 2009).

The Family is one of the theoretical axes of the Project. The family is the first place of belonging and child identity construction. It is the central point of the emergence of needs, for being the first place of socialization. The family is a resource for the development of the child (Chiesa \& Veríssimo, 2009).

Assess the child in the family context means the possibility of assessing the "heritage" of the family. Family heritage refers to the set of features that ensure greater security and standard of living. Contrary to what many think, heritage refers not only to material goods, but also to personal and relational skills. So intervene in a family context it is necessary not simply look to the needs, but rather strengthen their potential/their assets so that the family can overcome their needs (Solymos, Maricondi \& Soares, 2009).

In 2002 the Project was implemented in some areas of the municipality of São Paulo, but with the change of political parties in São Paulo the Project didn’t continued.

In a reality where professionals have difficulty in operationalizing Health Promotion actions because of the lack of technology, the pilot of the Project pointed out that the technologies could support the Health Promotion and Child Development actions, and strengthen families of children (Chiesa \& Veríssimo, 2009; Chiesa, 2005; Almeida, Fracolli, \& Chiesa, 2008).

In the context of the Family Health Strategy, the implementation of the Technologies of the Project becomes favorable, since they are validated to widen and improve the care of children, with emphasis on strengthening of child development. Thus in 2012 the School of Nursing of the University of São Paulo received a grant to do a second edition of the Project. In 2013, 30 Family Health teams from a region of São Paulo were capacitated to use the material in their practice. In 2014 we were invited to expand the Project to all regions of São Paulo municipality.

\section{Conclusion}

Like other international examples, the program "Our Children: Windows of Opportunities" has showed the potentiality to promote child development only by changing the perspective of the health teams when caring for the family and the child in clinical approaches and or specially when doing home visits. These technologies don't request a great investment by the government, but our greater challenge to put it in practice is to change the work logic that health professionals are inserted. Many health professionals don't have the abilities to deal with families in a different way that they are used to. They are used to traditional approaches focusing on anthropometric assessment of the child and neurodevelopment milestones. To change this perspective, it is necessary to work close to the health teams to ensure a greater success in achieving a transformation in the clinical practice, by supervising the health teams needs and helping them to work with the families.

\section{Acknowledgements}

We thank FAPESP for the grant for the second edition that allowed many health professionals to be trained to use the program.

\section{References}

Almeida, E. Z., Fracolli, L. A., \& Chiesa, A. M. (2008). Implemention of Project Our Children: Windows of Opportunities in the Family Health Team: Experience Report. Revista Paulista de Enfermagem, 27, 121-127.

Brazil. Ministry of Health (2006). Basic Health Secretary. Department of Basic Health. National Politic of Basic Health. Brasília: Ministry of Health,.

Brazil. Ministry of Health (2010). Health Police Secretary. Health Care Secretary. National Politic of Health Promotion (3rd ed.). Brasília: Ministry of Health. 
Chiesa, A. M. (2005). Autonomy and Resilience: Categories for the Empowerment for the Intervention in Basic Health on the Perspective of Health Promotion. Ph.D. Thesis, São Paulo: Nursing School of USP.

Chiesa, A. M., \& Batista, K. B. C. (2004). Challenge of the Implement for Family Health Program in a Big City: Reflexion about of the Experience in São Paulo City. Mundo da Saúde, 28, 42-48.

Chiesa, A. M., \& Veríssimo, M. D. L. O. R. (2009). The Sheet of Caring for the Children Health Promotion. In A. M. Chiesa, E. L. C. P. Zoboli, \& L. A. Fracolli (Org.), Children Health Promotion: The Experience of Our Children: Windows of Opportunities (pp. 75-94). São Paulo.

Chiesa, A. M., Veríssimo, M. D. L. O. R., \& Fracolli, L. A. (2009). The Project Our Children Windows of Opportunities: Possibilities and Limits for the Assistance of Children in the Family Health Program. In A. M. Chiesa, E. L. C. P. Zoboli, \& L. A. Fracolli (Eds.), Children Health Promotion: The Experience of Our Children: Windows of Opportunities (pp. 13-28). São Paulo.

Mustard, J. F. (2010). The Development of Early Childhood and Brain-The Basis for Health, Learning and Behavior during the Life. In M. E. Young (Org.), For Early Childhood to Human Development: Investing in Our Children's Future. Translate Magda Lopes (440 p). São Paulo: Foundation Maria Cecília Souto Vidigal.

Olds, D. L. (2006). The Nurse-Family Partnership: An Evidence Based Preventive Intervention. Infant Mental Health Journal, 27, 5-25.

Shore, R. (2000). Rethinking the Brain. Translate Iara Regina (160 p). Porto Alegre: Mercado Aberto.

Slade, A., Sadler, L., De Dios-Kenn, C., Webb, D., Currier-Ezepchick, J., \& Mayes, L. (2005). Minding the Baby a Reflective Parenting Program. Psychoanalytic Study of the Child, 60, 74-100.

Solymos, G. M. B., Maricondi, M. A., \& Soares, M. L. P. V. (2009). The Children and the Family: The Potential of Networked Approach to the Health Promotion Context. In: A. M. Chiesa, L. A. Fracolli, \& E. L. P. Zoboli (Org.), Children Health Promotion-The Experience of Project Our Children: Windows of Opportunities (pp. 43-60). São Paulo.

Young, M. E. (2010). Introduction and Overview. In: M. E. Young (Org.), For Early Childhood to Human Development: Investing in Our Children's Future. Translate Magda Lopes (440 p). São Paulo: Foundation Maria Cecília Souto Vidigal. 